\title{
Relationships between geology and composition of some pegmatitic monazites*
}

\author{
E. WM. HeInRICh \\ Department of Mineralogy, The University of Michigan \\ and \\ R. A. Borup and A. A. Levinsoy \\ The Dow Chemical Company, Freeport, Texas
}

(Received 18 December 1959)

\begin{abstract}
Fourteen monazites from several well-studied pegmatites and pegmatite districts in the western states have been analysed by X-ray fluorescence spectrometry for the cerium subgroup of rare-earth elements, as well as yttrium and thorium. The results have been correlated with the paragenesis, mineralogy and geology of the occurrences. They show several distinct, and in some cases unique. rare-earth element distributions which are characteristic not only of individual pegmatites but also of entire pegmatite districts.
\end{abstract}

\section{INTRODUCTION}

WI'HIx the last fifteen years there have appeared many new analyses of monazites in which individual rare-earth elements have been determined. Among the more significant results are those reported by Borovsky and GERAsImovsky (1945), Wylie (1950), Murata et al. (1953, 1957), Vainshtein et al. (1955, 1956a, b), and Semexov and Barinskir (1958). With a few exceptions the monazites analysed were selected from a wide geological variety of deposits and from many widelyseparated localities. Few data are available to test the compositional variation of monazites from a single deposit or from a group of related deposits. Murata et al. (1957) have analysed outer and inner parts in each of two crystals, one from Grama, São Paulo, Brazil, and the other from Hitterö, Norway. They have also analysed five monazites from the Shelby district, North Carolina; two are from quartz monazite pegmatite and three from the parent quartz monazite. Murata et al. (1958) have reported on the compositional variation in monazites from two Brazilian pegmatites.

'The objectives of this study were to determine the compositions of a group of monazites whose occurrences were accurately known, in order to obtain data on the following problems:

1. Whether different specimens of paragenetically identical monazite from a single deposit are compositionally identical or similar.

2. Whether specimens of paragenetically identical monazite from different pegmatites in a single district show any compositional variation.

3. General compositional variations within pegmatite districts.

'The fourteen monazites analysed in this study are all pegmatitic in origin and all but one were collected personally by Hersice from deposits in districts in the western United States (Table 3).

* Contribution from the Department of Mineralogy, The Lnivernity of Wichigan, Ann Arlyor. Michigan, No. 232. 


\section{X-Ray Fluorescence Ayalysis for Rare-earth Flements In Monazites}

$\mathrm{X}$-ray fluorescence spectrometry was used for the analysis of rare-earth elements in the monazites. The elements determined were lanthanum, cerium, praseodymium, neodymium, samarium, gadolinium, yttrium and thorium, which is commonly present in significant amounts. Based on previous work of a similar nature, the accuracy of the method is within $t 10$ per cent of the amount present for the less abundant elements and 55 per cent of the amount present for the more abundant elements (La, (Ce, Nd, Th).

\section{Equipment}

The standard Philips Electronics $X$-ray fluorescence equipment used in this work consisted of the $60 \mathrm{kV}, 50 \mathrm{~mA}$ power supply with voltage and amperage stabilizers. A FA-60 tungsten target tube was the $\mathrm{X}$-ray source, and the analysing crystal was lithium fluoride having a $2 d$ spacing of $4.028 \AA$. No collimation was used between the sample and the analysing crystal, but the standard 800-plate collimator was placed between the crystal and the Geiger tube detector. The diffractometer was fitted with a helium path attachment. Sample holders of plexiglass were $1 \frac{1}{4}$ in. wide, $1 \frac{3}{4}$ in. long by $\frac{1}{4}$ in. thick, with a cavity $\frac{3}{4}$ in. wide and $1 \frac{1}{6}$ in. Iong by $\frac{3}{18}$ in. deep. 'The Philips Electronics circuit panel was equipped with a recorder for qualitative scanning and counting circuitry for quantitative determinations.

\section{Preparation of samples and standards}

A weighed amount of the 400 -mesh monazite, usually $0.250 \mathrm{~g}$, was digested with $10 \mathrm{ml}$ concentrated sulphuric acid and finally taken to dryness. To this was added $9.750 \mathrm{~g}$ of acid-washed $\mathrm{SiO}_{2}$ of 400 -mesh size, and the mixture was then ground in a suitable ceramic mortar until a completely uniform sample was obtained. Uniformity was determined by periodically examining a sample by means of $X$-ray fluorescence until reproducible intensities were obtained for one or more of the elements under examination. Standards consisting of known amounts of the several elements were made up in a similar manner in $\mathrm{SiO}_{2}$. The concentration of the standards varied from 0.5 per cent by weight for lanthanum and cerium to $0 \cdot 1$ per cent by weight for yttrium.

For the sample size of $0.250 \mathrm{~g}$ and the amount of $\mathrm{SiO}_{2}(9.750 \mathrm{~g})$, a dilution factor of 1:40 was obtained. This reduced the amount of any element to a reasonably small concentration in the sample and thus minimized any absorption edge or enhancement effects.

\section{Procedure}

Samples and standards were firmly packed into the plastic holders to form a smooth, dense surface which could be easily reproduced. The holder was then placed into the beam of $\mathrm{X}$-rays and the helium stream was turned on. The diffractometer was manually set to the predetermined angle for the desired element, and the signal was measured on the count register. Background measurements were made in a similar manner at a $2 \theta$ setting in a clear region as close as possible to the $2 \theta$ setting for the sample. Suitable counting times were used so as to obtain 
statistically meaningful data. Table 1 contains the data as determined on monazite specimen no. 5201 . The power factors used were $45 \mathrm{kV}$ and $25 \mathrm{~mA}$ for all elements except thorium. The standard used for thorium was best handled at $45 \mathrm{kV}$ and $15 \mathrm{~mA}$.

Cerium was the only element which would not produce a strong line in a clear region. The best line for this element was superimposed upon the tungsten $L_{B_{1}}$ second-order line. The contribution for this tungsten order was determined and

Table 1. Analytical data for specimen no. 5201

\begin{tabular}{|c|c|c|c|c|c|c|c|c|}
\hline Wlement & $\begin{array}{l}= \pm \theta \\
\text { peak }\end{array}$ & $\begin{array}{c}20 \\
\text { back- } \\
\text { ground }\end{array}$ & $\begin{array}{c}\text { Teak } \\
\text { (counts/seo) }\end{array}$ & $\begin{array}{l}\text { Background } \\
\text { (counts/sec) }\end{array}$ & $\begin{array}{c}\text { Nett } \\
\text { (counts/sec) }\end{array}$ & $\begin{array}{l}\text { (Standard) } \\
\text { per unit of } \\
\text { element in } \\
\mathrm{SiO}_{2}\end{array}$ & $\begin{array}{c}\text { Dilution } \\
\text { conversion } \\
\text { factor }\end{array}$ & $\begin{array}{c}\text { \% element } \\
\text { as oxide in } \\
\text { monarito }\end{array}$ \\
\hline Lat & $82 \cdot 93$ & $81 \cdot 00$ & 64 & 32 & 32 & $68 / 0 \cdot 5 \% / 6$ L L & 40 & $11.0 \% \mathrm{La}_{2} \mathrm{O}_{3}$ \\
\hline $\mathrm{Co}$ & $79 \cdot 08$ & 81.00 & $136^{*}$ & 32 & 104 & $82 / 0.5 \%$ & 41) & $29.7 \% \mathrm{Ce}_{2} \mathrm{O}_{3}$ \\
\hline $\mathrm{Pr}$ & $68 \cdot 32$ & $67 \cdot 40$ & 56 & 37 & 19 & $48 / 0.2 \% \mathrm{Pr}$ & 40 & $3.7 \% \mathrm{Pr}_{2} \mathrm{O}_{3}$ \\
\hline $\mathrm{Nd}$ & $65 \cdot 22$ & $6=001$ & 140 & 43 & 97 & $63 / 0+2 \% \mathrm{Nd}$ & 40 & $14.4 \% \mathrm{Nd}_{2} \mathrm{O}_{3}$ \\
\hline $\mathrm{Sm}$ & $59 \cdot 64$ & $62 \cdot 00$ & 83 & 43 & 40 & $106 / 0.2 \% \mathrm{sm}$ & 40 & $3.5 \% \mathrm{Sm}_{2} \mathrm{C}_{3}$ \\
\hline Gd & $54 \cdot 74$ & $50 \cdot 00$ & 82 & 63 & 19 & $104 / 0.1 \% \mathrm{Gd}$ & 40 & $0.8 \% \mathrm{Gd}_{2} \mathrm{O}_{3}$ \\
\hline$Y$ & $23 \cdot 97$ & $23 \cdot 00$ & 187 & 73 & 114 & $197 / 0.1 \% Y$ & 40 & $2.9 \% \mathrm{Y}_{2} \mathrm{O}_{3}$ \\
\hline Th & $27 \cdot 64$ & $26 \cdot 90$ & 136 & 43 & 93 & $116 / 0.2 \% \mathrm{Th}$ & 40 & $7.3 \%$ Tho \\
\hline
\end{tabular}

the total signal was corrected by this amount. The cerium standard was corrected in a like manner, and suitable data for cerium were thus obtained. The use of pulse-height discrimination in conjunction with a scintillation counter would simplify the determination for cerium.

\section{Geology of The Specimens}

Petaca District, New Mexico

The geology and mineralogy of the Petaca pegmatites have been described by JaHNS (1946). The pegmatites possess well-developed zones and albite-rich replacement units. Characteristic and widely-distributed accessory minerals are garnet, green and purple fluorite, columbite, monazite, samarskite, cyrtolite, ilmenite, beryl and rose muscovite (Henrich and Levinson, 1953). Monazile, which has been found in fifty-seven deposits or 83 per cent of all deposits examined, is closely associated with columbite, samarskite and purple fluorite in strongly albitized parts of pegmatites. The monazite varies in size from microscopic grains to masses about 6 in. across, weighing as much as $9 \mathrm{lb}$. The mineral commonly is a medium reddish brown in colour. The formation of the monazite is part of the mineralization accompanying the extensive albitization, and the monazite is believed by the writer (HEINRICH) to be of hydrothermal origin.

Monazites from the following deposits were analysed:

1. North Star pegmatite. Tablets occur up to $\mathrm{l}$ in. long and $\frac{1}{2} \mathrm{in}$. thick Analyses nos. $5185,5186,5187$.

2. Coats pegmatite. Blocky crystals from 2 to 6 in. across. Analyses nos. 5188,5197 .

3. Fridlund pegmatite. Tablets as much as 1 in. in length. Analysis no. 5189. 


\section{Elk Mountain District, New Mexico}

The Elk Mountain district, in San Miguel County, also has been studied by JAHNS (1946). Monazite from a pegmatite near the head of Manzanares Creek between Cow Creek and Bull Creek, 14 miles north-east of Pecos, has been analysed (no. 5190). The dikes in this part of the district are zoned and locally albitized, containing accessory spessartite, fluorite, columbite and monazite. Gadolinite also is reported. These accessories are associated with secondary albite, and the monazite is regarded as similar in origin to that of the Petaca district.

\section{Brown Derby Pegmatites, Colorado}

The Brown Derby pegmatites in the Quartz Creek district of Gunnison County have been intensively studied (Hanley et al., 1950; StaAtz and Trites, 1955). Monazite has been found in twenty-six pegmatites in the district, or about 1.4 per cent of those studied. It occurs in unzoned, zoned and complex pegmatites, chiefly in wall zones and intermediate zones. Common associates are quartz, oligoclase-albite, microcline, muscovite and black tourmaline. Three monazites from this district were analysed (nos. 5195, 5196, 5202). Their occurrence and geology are as follows:

No. 5195. Monazite in excellent euhedral crystals as much as $2 \mathrm{in.}$ long, 1 in. across and $0 \cdot 4$ in. thick, in the eastern arm of Brown Derby no. 2. This occurrence is referred to by StaAtz and TriTes (1955, p. 76) as being in the Brown Derby no. I dike (their no. 452) but actually is in a split from the southern end of Brown Derby no. 2 (their no. 453). The unit, formerly exposed only in pit no. 11 , forms a lens about $1 \mathrm{ft}$ thick and not more than $20 \mathrm{ft}$ long. It contains chiefly albite with less abundant quartz, and accessory zinnwaldite, spessartite, gahnite, blue tourmaline, monazite and columbite. The unit, which is estimated to contain $2 \cdot 2$ per cent monazite and 1.4 per cent columbite (STAATZ and TRITES, 1955, p. 76), is separated from the hanging wall contact by a 4 to 6 in. border zone chiefly of albite and quartz. Structurally the unit represents a mineralogically unusual phase of the wall zone, localized beneath a structural roll in the hanging wall contact.

No. 5196. Monazite in anhedral pods as much as 4 in. across in the northern part of the Brown Derby no. 1 pegmatite. The mineral occurs in the wall zone consisting mainly of albite, quartz, microcline and muscovite, associated with clusters of muscovite books and corroded by aggregates of schorl.

No. 5202. Monazite in small $\frac{1}{2}$ in. tablets from small pegmatite, Brown Derby no. 7 (Staatz and Trites, 1955, no. 458) north of Brown Derby no. 2, containing albite, quartz, microcline, muscovite, and a trace of beryl.

In all three of these occurrences the monazite is in wall-zone rock and is believed to be magmatic in origin.

\section{Trout Creek Pass Area, Colorado}

The zoned pegmatites in the Trout Creek Pass area, in Chaffee County, contain accessory euxenite, allanite monazite, fluorite, haematite, garnet, apatite and anatase (pseudomorphous after ilmenite). The monazite, which is closely associated with fluorite and euxenite, forms tabular masses as large as $4.5 \times 2.5 \times 2$ in. (HEINRICH, 1948). These minerals occur in small masses of albite-rich pegmatite 


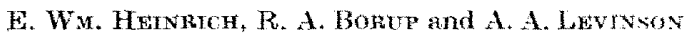

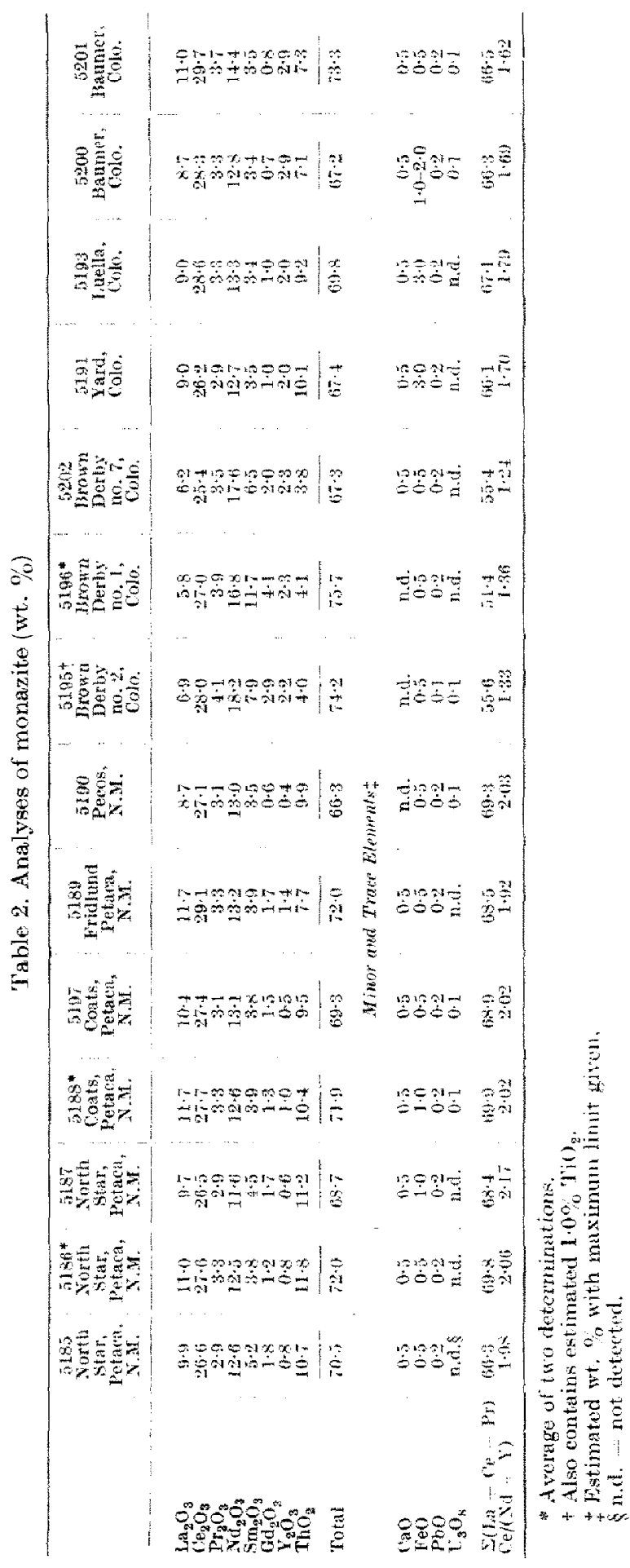


formed by replacement of marginal parts of quartz-microcline cores. Two monazites from dikes in this area have been analysed: no. 5191 from the Yard pegmatite and no. 5193 from the Luella pegmatite (HEINRICH, 1948).

\section{Guffey Area, Colorado}

One pegmatite in the Guffey area in Park County, the Baumer pegmatite (HEINRICH and BEVER, 1957), contains accessory euxenite, monazite, allanite, and radioactive ilmenite. The monazite (nos. 5200 and 5201) forms euhedral to subhedral crystals, as large as $1 \frac{1}{8} \times 1 \times \frac{1}{8}$ in., closely associated with euxenite or intergrown with it, in wall zone rock close to contacts with a quartz-microcline core. The wall zone contains mainly microcline, oligoclase, quartz and biotite. The monazite and euxenite are primary constituents of this unit.

\section{Results of Analyses ayd Discussion}

The analytical results are presented in Table 2. Descriptions of the analysed monazites are given in Table 3. Noteworthy relations in these analyses are:

(1) In all monazites, Nd $>$ La. This is the first set of analyses to show consistently Nd $>$ La since the initial work of Goldschmid T and Thomassex(1924) on Norwegian monazites (although about 10 per cent of the analyses in the literature have this relationship). Furthermore, the Nd/La ratio appears to be a district or "regional" characteristic of rare-earth distribution.

(2) In the three Brown Derby examples, Sm $>$ La. No other analyses of monazites in the literature show this distribution.

(3) In all cases, $\mathrm{Sm}>\mathrm{Pr}$. 'This distribution has been previously noted only rarely in monazites.

(4) A very limited range of $\mathrm{Ce}$ and $\mathrm{Pr}$.

(5) A wide range of $Y, G d$ and $T h$.

It is also noteworthy that the quantity sigma ( $\Sigma)$, which is the sum of the atomic percentages of La, Ce and Pr proposed by Murata et al. (1953) as an index for the composition of cerium-earth minerals, is in the range 51-55 for the three Brown Derby monazites, the previously reported low being 58. The low sigma value means these monazites are considerably enriched in the heavier lanthanides in comparison to most other monazites. The possibility that available lanthanum may have been captured in potassium minerals was considered, but none (our limit of sensitivity is estimated to be 25 p.p.m.) was found by emission spectroscopy in mierocline, cleavelandite or muscovite, as well as in euxenite from these pegmatites. The relatively-low contents of La and $\mathrm{Pr}$ with the corresponding abundance of $\mathrm{Nd}$ and $\mathrm{Sm}$ in these samples is perhaps analogous to some monazites noted by Vainshitern $t$ al. (1956b), from Fennoscandavia and other areas. They noted a "pegmatitic effect", in which there was a significant enrichment of Sm and the heavier rare earths and a decrease in La and Ce in certain pegmatitic monazites in comparison to monazites from the parent granites. Although no monazite has been reported from the parent granite of the Brown Derby pegmatites, an analysis of such a monazite seems desirable.

Inspection of analyses 5185, 5186, 5187 (Table 2) from the North Star pegmatite shows that specimens of paragenetically identical monazites from a single pegmatite 
are remarkably uniform in their rare-earth composition. These analyses show also that there is about the same order of variation between the two composite samples $(5185,5186)$ as there is between the composites and the single-crystal sample (5187). This is in accord with results by Murata et al. (1957), who showed that analysis of duplicate samples of monazites (their nos. 6 and 19) from quartz monzonite in the Acre Rock quarry, Shelby district, North Carolina, gave very close results for the

Table 3. Description of analysed specimens

\begin{tabular}{|c|c|c|c|}
\hline No. & Locality & Deseription & Origin \\
\hline 5185 & $\begin{array}{l}\text { North star pegmatite, } \\
\text { Petaca dist., N.M. }\end{array}$ & $\begin{array}{l}\text { Composite sample from many crystals } \\
\text { and grains; light brown. }\end{array}$ & Replacement \\
\hline 5186 & $\begin{array}{l}\text { North Star pegmatite, } \\
\text { Petaca dist., N.M. }\end{array}$ & $\begin{array}{l}\text { Composite sample from many erystals } \\
\text { and grains; medium brown. }\end{array}$ & Replacement \\
\hline 5187 & $\begin{array}{l}\text { North Star pegmatite, } \\
\text { Petaca dist., N.M. }\end{array}$ & Part of a single crystal dark brown. & Replacement \\
\hline 5188 & $\begin{array}{l}\text { Coats pegmatite, } \\
\text { Petaca dist., N.M. }\end{array}$ & $\begin{array}{l}\text { Composite sample from several } \\
\text { crystal fragments. }\end{array}$ & Replacement \\
\hline 5197 & $\begin{array}{l}\text { Coats pegmatite, } \\
\text { Petaca dist.. N.M. }\end{array}$ & $\begin{array}{l}\text { Fragment from a single large } \\
\text { crystal. }\end{array}$ & Replacement. \\
\hline 5189 & $\begin{array}{l}\text { Fridlund pegmatite, } \\
\text { Petaca dist., N.M. }\end{array}$ & Fragment from a single erystal. & Replacement \\
\hline 5190 & $\begin{array}{l}\text { Manzanares Creek, } \\
\text { Pecos, N.M. }\end{array}$ & Fragment from a single crystal. & $\begin{array}{l}\text { Trobably } \\
\text { replacement }\end{array}$ \\
\hline 5195 & $\begin{array}{l}\text { Brown Derby no. } 2 \\
\text { pegmatite, eastern arm, } \\
\text { Gunnison Co., Colo. }\end{array}$ & A single euhedral crystal. & Magmatic \\
\hline 5196 & $\begin{array}{l}\text { Brown Derby no. l } \\
\text { pegmatite, Gunnison } \\
\text { Co., Coln. }\end{array}$ & $\begin{array}{l}\text { Part of a large single corroded } \\
\text { erystal. }\end{array}$ & Magmati \\
\hline 5202 & $\begin{array}{l}\text { Brown Derby no. } 7 \\
\text { pegmatite, Gunnison } \\
\text { Co., Colo. }\end{array}$ & A single erystal. & Magmatic \\
\hline 5191 & $\begin{array}{l}\text { Yard pegmatite, } \\
\text { Trout Creek Pass, Colo. }\end{array}$ & $\begin{array}{l}\text { Composite from several crystal } \\
\text { fragments. }\end{array}$ & Replacement \\
\hline 5193 & $\begin{array}{l}\text { Luella pegmatite, } \\
\text { Trout Creek Pass, Colo. }\end{array}$ & $\begin{array}{l}\text { Composite from several crystal } \\
\text { fragments; dark brown. }\end{array}$ & Replacement \\
\hline 5200 & $\begin{array}{l}\text { Baumer pegmatite, } \\
\text { Guffey area, Colo. }\end{array}$ & Part of single subhedral crystal. & Magmatie \\
\hline 5201 & $\begin{array}{l}\text { Baumer pegmatite, } \\
\text { Guffey area, Colo. }\end{array}$ & $\begin{array}{l}\text { Part of single subhedral crystal; } \\
\text { closely associated with euxenite. }\end{array}$ & Magmatic: \\
\hline
\end{tabular}

rare earths. Their results show a much greater ThO $\mathrm{O}_{2}$ variation $(10.9$ and 7.7 per cent) than do ours $(10 \cdot 7,11.8$ and 11.2 per cent).

Similarly a comparison of the two analyses $(5188,5197)$ of Coats monazite and of the two analyses of Baumer monazite $(5200,5201)$ emphasizes the relative uniformity of composition of paragenetically identical monazites from the same pegmatite. In both eases the $\Sigma$ 's and the $\mathrm{Ce} /(\mathrm{Nd}+\mathrm{X})$ ratios (suggested by Murate et al., 1957) are very close.

Paragenetically-identical monazites from different pegmatites in the same district $(5185,5186,5187,5188,5197,5189)(5195,5196,5202)(5191,5193)$ also 
show but minor rare-earth variations and a somewhat greater thorium variation, although by no means as large as between districts. Three distinct groupings of the monazites on the basis of their rare-earth distribution can be made: (a) the Petaca + the Pecos monazites $(\Sigma=66 \cdot 3-69 \cdot 9)$; (b) the Trout Creek Pass + the Baumer monazites $(\Sigma=66 \cdot 1-67 \cdot 1)$; and (c) the Brown Derby monazites $(\Sigma=51 \cdot 4-55 \cdot 6)$. It is noteworthy that the Elk Mountain pegmatites (Pecos monazite) are mineralogically and geologically similar to those of the Petaca

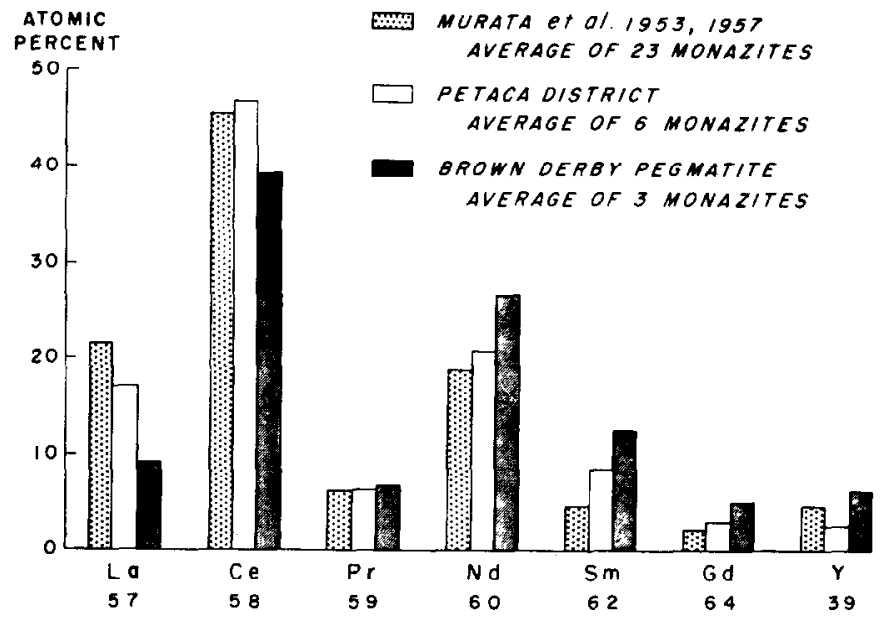

Fig. 1. Graphic presentation of rare-earth element distribution in selected monazites. (Numbers below chemieal symbols are atomic numbers.)

district, and the two groups may be consanguineous. Likewise the Baumer pegamatite and those of Trout Creek Pass may well belong to the same pegmatite clan on the basis of mineralogy and geology. Thus, for the monazites here studied there appears to be a rare-earth element distribution that is characteristic for a particular pegmatite district. Fig. 1 presents a graphical comparison of the rareearth distribution of monazites from the Brown Derby and Petaca districts, as well as an average of the twenty-three monazites analysed by Murata et al. (1953, 1957). To a somewhat lesser degree the Th content for a particular district appears restricted to a characteristic range. The data suggest that it may well be possible to correlate pegmatites on the basis of the rare-earth element distribution in their monazites.

The Brown Derby monazites are the only oncs of the group not closely or commonly associated with a radioactive multiple-oxide mineral such as samarskite or euxenite; they also are very low in thorium. The Brown Derby monazites also are clearly magmatic in origin.* The Baumer monazites also are probably magmatic and are second lowest in thorium content. That any more general significance can be attached to this relationship seems unlikely inasmuch as

* For detailed presentations of the data on internal structures, mineral parageneses and conclusions on the origins of the monazites in the various districts, referenes may be made to the literature for the various districts: JAHNS (1946), STAATZ and Trites (1955), HANLEY et al. (1950), HeINRICh and Bever (1957). 
Murate et al. (1957, monazites 6 and 19) found less thorium in a pegmatitic monazite than in a monazite from the genetically related normal quartz monazite. Thorium variations appear to be relatable chiefly to district characteristics.

\section{Distribution of Thorium}

Autoradiographs were prepared of specimens from nearly all of the localities represented by the analysed monazites. The autoradiographs display three types of density patterns:

1. Essentially homogeneous distribution of the radioactive elements (North Star, Coats, Brown Derby no. 1 and no. 2, Yard, Luella).

2. Crystallographically oriented zones of contrasting radioactivity (Brown Derby no. 1, Fridlund).

3. Non-systematic variations in radioactivity (North Star, Pecos, Luella, Baumer).

Although the differences in intensity are slight, they are readily discernable on autoradiographs of $15 \mathrm{hr}$ exposure. These autoradiographs also clearly reflected the differences in overall $\mathrm{ThO}_{2}$ content revealed by the analyses: the antoradiographs of the Brown Derby specimens were by far the lightest.

Acknowledgements - The writers are indebted to 'The Dow Chemical Company for permission to publish the results of the analyses, and to the Michigan Memorial-Phoenix Project for support of various phases of the laboratory study of the minerals under Project no. 150. They also are grateful to H. J. RosE, JR., of the U.S. Geological Survey for supplying a specimen of monazite analysed by emission spectroscopy in order that we could confirm the reliability of our standards. This comparison is as follows (U.S. Geological Survey sample 516007):

\begin{tabular}{l|c|c}
\hline & $\begin{array}{c}\text { U.S. Geol. Survey } \\
\text { emission spectroscopy } \\
\text { (wt. \%) }\end{array}$ & $\begin{array}{c}\text { This paper } \\
\text { X-ray fluorescence } \\
\text { (wt. \%) }\end{array}$ \\
$\mathrm{La}_{2} \mathrm{O}_{3}$ & $24 \cdot 9$ & $25 \cdot 5$ \\
$\mathrm{CeO}_{2}$ & $48 \cdot 2$ & $49 \cdot 6$ \\
$\mathrm{Pr}_{6} \mathrm{O}_{11}$ & $5 \cdot 1$ & $4 \cdot 4$ \\
$\mathrm{Nd}_{2} \mathrm{O}_{3}$ & $16 \cdot 8$ & $16 \cdot 3$ \\
$\mathrm{Sm}_{2} \mathrm{O}_{3}$ & $2 \cdot 2$ & $2 \cdot 5$ \\
$\mathrm{Gd}_{2} \mathrm{O}_{3}$ & $0 \cdot 6$ & 0.3 \\
$\mathrm{Y}_{2} \mathrm{O}_{3}$ & $1 \cdot 8$ & $1 \cdot 5)$ \\
\hline
\end{tabular}

\section{REFERENCES}

Bonovsky I. B. and Gerasimovsky V. I. (1945) Rare earths in minerals. C.R. Acal. Sei., U.S.S.R. 49, 353-356.

Goldschmidt V. M. and Thomassen L. (1924) Geochemische Verteilungsgesetze der Elemente-III. Roentgenspektrographische Untersuchungen ueber die Verteilung der seltenen Erdmetalle in Mineralen. Skr. Vidensk. Selsk., Christ. 5, 1-50.

Hanley J. B., Hernrich E. Wm. and Page I. R. (1950) Pegmatite Investigations in Colorado, Wyoming and Utah, 1942-1944. U.S. Geol. Survey Prof. Paper 227.

Heinrich E. Wm. (1948) Fluorite rare earth mineral pegmatites of chaffee and Fremont counties, Colorado. Amer. Min. 33, 64-75. 
Heinkich E. Wm. and Bever J. E. (1957) Radiouctive mineral occurrences in the (ituffey aren, Park and Fremont counties, Colorado. Colo. School Mines Quart. 52, (4), 23-35.

Heinrich E. WM. and Levinson A. A. (1953) Studies in the mica group); mineralogy of the rose muscovites. Amer. Min. 38, 25-49.

JAhns R. H. (1946) Mica Deposits of the Potaca District, Rio Arriba County, New Mexico. New Mex. Bur. Mines Min. Res. Bull. 25.

Murata K. J., Rose H. J. JR. and Carron M. K. (1953) Systematic variation of rare carths in monazite. Geochim. et Cosmochim. Acta 4, 292-300.

Murata K. J., Rose H. J., Jr., Carrox M. K. and Giass J. J. (1957) Systematic variation of rare-earth elemonts in cerium-earth minerals. Geochim. et Cosmochim. Acta 11, 141-161.

Murata K. J., Dutra C. V., Trixeira da Costa M. (1958) Composition of monazites from pogmatitos in oastorn Minas Goraif, Brazil. Geochim. et Cosmochim. Acta 16, 114.

Semenov E. I. and Barisskil R. I. (1958) Compositional characteristics of rare earths in minorals. Geoklimiya (4), 314-333.

Strantz M. H. and Trites A. F. (1955) Geology of the Quartz Croek Pogmatite District, Gunnison County, Colorado. U.S. Geol. Survey Prof. Paper 265.

Vainshtein E. E., Tugarinov A. I. and Turanskaya N. V. (1955) The distribution of rare earths in monazites. Dokl. Akad. Nauk SSSR 104, 268-271.

Vainshtein E. E., TVgarinov A. I. and Turanskaya N. V. (1956a) Distribution of the rare earths in monazites of granitoids. Dokl. Akad. Nauk SSSR 108, 691-692.

Vainshtein E. F., Tugarinov A. I. and Turasskaya N. V. (1956b) On regularities in the distribution of rare earths in some minerals. Geokhimiza 36-56.

Wylie A. W. (1950) Composition of some Australian monazites. Aust.J. Appl. Sci. 1, 184-171. 